\title{
A s novým rokem přichází nové zákony
}

Vážení čtenáři,

s novým rokem přichází i nové zákony, anebo přesněji řečeno nastává účinnost mnoha nových zákonů ${ }^{1}, \mathrm{z}$ nichž některé prřšly na svět tak rychle a nenápadně, že jsou proto odbornou i laickou veřejností přijímány s netajenou nedůvěrou. Hlavní pozornost se přitom soustřed'uje na dva z nich, a to na nový občanský zákoník a zákon o obchodních korporacích, které byly přijaty již na začátku roku 2012, a bylo tak možné se na jejich důsledky do určité míry připravit.

Nicméně to není snadné, nebot' nový občanský zákoník obsahuje 3081 paragrafů a vládní návrh k tomuto zákonu spolu s důvodovou zprávou a př́lohou byl předložen na 1206 stranách textu. Tento zákon současně ruší hned 70 zákonů či jiných právních předpisů (včetně dosud platného starého občanského zákoníku č. 40/1964 Sb. a obchodního zákoníku č. 513/1991 Sb.) a novelizuje 114 dalších zákonů a dalších právních předpisů. Zákon o obchodních korporacích je oproti tomu o něco slabší, když se skládá jen ze 786 paragrafů a text vládního návrhu spolu $\mathrm{s}$ důvodovou zprávou a prílohou se vešel na 308 stran textu.

Přečíst a prostudovat tolik stran textu je náročné nejen pro lidi bez právního vzdělání, ale i pro samotné právníky. Tyto zákony přitom nespočívají jen v drobných úpravách, ale přináší sebou zásadní změny koncepčního pojetí. Důvodová zpráva k novému občanskému zákoníku vyznívá sice celkem přesvědčivě, nicméně většině čtenářů se může jevit jako příliš zbytečně mnohoslovná. ${ }^{2}$ Ideový zdroj návrhu zákona tvoří podle této důvodové zprávy „,vládní návrh občanského zákoníku bývalého Československa z r.1937“ sledujíc přitom „modernizační revizi rakouského všeobecného zákoníku občanského (ABGB) z r. 1811 v jeho konfrontaci s novějšimi evropskými zákoníky, zejména německým a švýcarským. “A tak v našem soukromém právu, nyní v sjednoceném právu občanském a soukromém, mizí některé staré a zažité pojmy, jako je např. „podnik“ a zavádí pojmy nové jako např. „obchodní závod“ či „závdavek“汭. Obchodní společnosti a družstva jsou nuceny upravit své společenské smlouvy a vyhodnotit své smluvní vztahy ve vztahu k obchodním partnerům podle nových pravidel. To všechno vyžaduje určitý čas na studium, konzultaci s právníky a nemalé peněžní výdaje.

Slavný řecký vědec Archimédes kdysi prohlásil: „Dejte mi pevný bod ve vesmíru a já pohnu celou Zemi“ ${ }^{\text {‘4 }}$. Z pohledu podnikatelské sféry si dovolím tento citát upravit následovně: „Dejte nám neměnné právní predpisy, nechte nás podnikat a my budeme vydělávat a odvádět daněc. Nejhorší pro podnikatele jsou totiž „reformy pro reformy“, které volení zástupci přijímají pouze proto, aby mohli vykázat nějakou činnost. $Z$ teoretického hlediska vidím potom problém $\mathrm{v}$ tom,

1 Jedná se především o následující zákony a zákonné opatření:

a) zákon č. 89/2012 Sb. ze dne 3. února 2012 občanský zákoník (dále v textu „nový občanský zákoník),

b) zákon č. 90/2012 Sb. ze dne 25. ledna 2012 o obchodních společnostech a družstvech (dále v textu ,zákon o obchodních korporacích"),

c) zákon č. 91/2012 Sb. ze dne 25 . ledna 2012 o mezinárodním právu soukromém,

d) zákon č. 303/2013 Sb. ze dne 12. záríi 2013, kterým se mění některé zákony v souvislosti s přijetím rekodifikace soukromého práva,

e) zákon č. 304/2013 Sb. ze dne 12. září 2013 o veřejných rejstřících právnických a fyzických osob,

f) zákonné opatření Senátu č. 344/2013 Sb. ze dne 10. ř́ina 2013 o změně daňových zákonů v souvislosti s rekodifikací soukromého práva a o změně některých zákonů.

2 Vláda ČR: Dưvodová zpráva k novému občanskému zákoníku. [online]. Praha, Poslanecká sněmovna České republiky, c2011, [cit. 2. 1. 2014], <http://www.psp.cz/sqw/text/tiskt.sqw?O=6\&CT=362\&CT1=0>.

3 Blíže viz Vomáčková, H.: Podnik nebo závod obecně a v účetni praxi. Český finanční a účetní časopis, 2009, roč. 9, č. 1, s. 118-124, a Svoboda, M.: Dopady Nového občanského zákoníku do účetního výkaznictví-účetní zobrazení závdavku. Český finanční a účetní časopis, 2009, roč. 9, č. 1, s. 125-131.

4 Citováno poprvé v knize Synagoge od Pappose z Alexandrie (290 př. n. 1. - 350 př. n. 1.). 
že efekt plynoucí ze změny zákona se obtížně měří. Ve své podstatě lze tento efekt vyjádřit jako rozdíl mezi přínosy a náklady spojenými se změnami zákona. Do těchto nákladů však nesmíme zapomenout zahrnout i náklady na vzdělávání a na konzultaci s odborníky. Jsou-li však změny př́lilš časté nebo přicházejí-li najednou př́iliš veliké, dostávají se zvláště drobní podnikatelé a manažeři stř̌edních a malých firem, kteří si nemohou dovolit drahé konzultanty, do stavu určité duševní odevzdanosti, nebot' nejsou schopni všechny změny pochopit a zapracovat, a tudíž jen trpně očekávají, co jim přinese další vývoj. Do nákladů spojených se změnami zákona je potom nutné započítat i ztráty na výdělku a sankce, pokuty, penále, nebo jiné postihy od regulatorních orgánů či dokonce na základě soudního rozhodnutí.

Zda nové zákony přinesou kladný nebo záporný efekt plynoucí ze změny zisku ukáže ovšem až čas.

prof. Ing. Petr Marek, CSc.

předseda redakční rady

Českého finančního a účetního časopisu 